\title{
CAVE MOTH AND BUTTERFLY FAUNA (Insecta: Lepidoptera) OF SERBIA: CURRENT STATE AND FUTURE PROSPECTS
}

\author{
PREDRAG JAKŠIĆ ${ }^{*}$ \\ ${ }^{1}$ Faculty of Sciences and Mathematics, University of Niš, Niš, Serbia
}

\begin{abstract}
A history of the study of Lepidoptera in caves in Serbia is given. On this basis, a comparative analysis with Lepidoptera species in neighboring countries - Croatia, Romania and Bulgaria, was carried out. The presence of cavernicolous habitats and ecological niches suitable for Lepidoptera was investigated. There is a need to investigate these groups of organisms in Serbia and it is suggested that caves in Serbia be a priority in this research.
\end{abstract}

Keywords: Lepidoptera, caves, habitats, Serbia.

\section{INTRODUCTION}

Carbonate sedimentary rocks (limestone and dolomites) are widespread on the Balkan Peninsula and possess a variety of speleological features, including caves, which are very important to wildlife. It is thought that there are several thousand caves, each providing a suitable habitat for a variety of living organisms. The Balkan Peninsula is considered to be an important center of cave fauna diversity in the world.

In Serbia, parts of the Dinarides and Carpatho-Balkan Mountains are found, with numerous caves, giving it an advantage over other Balkan countries. However, this advantage has not been adequately exploited in the case of cave fauna. There are very few studies on the cave fauna of Serbia. Pretner (1963) registers around 30 endemic species, predominantly Coleoptera, in the caves of Serbia. Ćurčićet et al. (1997), lists 29 species representing different groups in the Zlotska Cave, among which 13 are endemic in caves of the Carpatho-Balkan loop. Every year, intensive research describes numerous species new to science, but a summary of the results depicting the wealth of cave fauna in Serbia is still to come.

Results so far offer little specific data regarding representatives of the Lepidoptera order in caves in Serbia. The goal of this work was to present the current situation and future prospects in the study of Lepidoptera in Serbian caves, and to compare the faunistic abundance in Serbia with that of this group of insects in neighboring countries. One of the tasks was to analyze the cave habitats suitable for the survival of Lepidoptera according to contemporary habitat classification systems, and to show the specific elements of Lepidoptera ecology conditioned by living in caves. It is also important to underline the importance of the protection and monitoring of cave-dwelling Lepidoptera, and to encourage the study of this group of organisms in Serbia.

\footnotetext{
* Corresponding author: jaksicpredrag@ gmail.com BIOLOGY
}

\section{MATERIALS AND METHODS}

By analyzing the literature for Serbia and the countries chosen for comparison - Croatia, Romania and Bulgaria, a list of Lepidoptera species found caves was made. The taxonomic order and nomenclature assigned to the species are according to Karsholt \& Razowski (1996). The ecological status of these species (troglophile, trogloxene, subtroglophile) is based on the reports of the authors of the works given in Table 1. An overview of the cavernicolous habitats suitable for Lepidoptera is presented according to the EUNIS habitat classification (Anonymous, 2007-2012). The overview of ecological niches suitable for Lepidoptera is according to Jakšić (2005).

\section{RESULTS}

Jovanović (1891), was the first to report the finding of moths in one of the caves in the Sićevo Gorge. The systematic study of Lepidoptera fauna in Serbian caves dates from the period between the two World Wars. In 1923, the Institute of Speleology "Emil Racoviță", Cluj, Romania, organized a study of the cave fauna of Serbia. This research was led by Dr. René Jeannel (1879-1965) and Dr. Siniša Stanković (1892-1974) with a team of four biospeleologists. During June and July, the team visited over 20 caves in eastern and western Serbia. Lepidoptera material was also collected in Hadži Prodan's Cave, but the names of the species were not given Jeannel \& Stanković (1924). More detailed results were reported later Jeannel \& Racovitza (1929), when the presence of Lepidoptera in four caves was cited, without specifying the species. In 1933, biospeleological research was conducted in the caves of eastern and western Serbia, as well as eastern Montenegro (around Pljevlja), led by Dr. Paul Remy (1894-1962). In the published report, four species of Lepidoptera found in caves around Prijepolje are presented. In his analysis of habitats in Lazar's (Zlotska) Cave, Jakšić (2005) noted the presence of two species of Lepidoptera. 
These results show that five species of Lepidoptera have been found in the caves of Serbia. Table 1 presents the overall data regarding the presence of Lepidoptera in Serbia and the neighboring countries of Croatia, Romania and Bulgaria.

Table 1. Comparative overview of cave fauna. The species identification number (ID) is according to Karsholt \& Razowski (1996).

Croatia: (Kučinić, 1990; 2002; Matočec \& Ozimec, 2001). Romania: (Rakosy, 2003-2004. Serbia: (Remy, 1953; Jakšić, 2005).

Bulgaria: (Beron, 1994, 2016; Beshkov \& Langourov, 2004, 2011; Beshkov \& Petrov, 1996; Kostova et al., 2016; Zagulajev, 2000). Ecological status (ES): Tp - troglophile, Tx - trogloxene, Stp - subtroglophile.

\begin{tabular}{|c|c|c|c|c|c|c|c|}
\hline Nbr. & ID & Family and species & 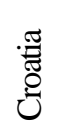 & 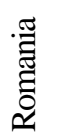 & $\begin{array}{l}\text { 递 } \\
\text { हैं }\end{array}$ & 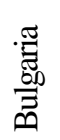 & ES \\
\hline & & Fam. TINEIDAE & & & & & \\
\hline 1 & 475 & Haplotinea ditella (Pierce \& Diakonoff, 1938) & & O & & & \\
\hline 2 & 623 & Nemapogon granella (Linnaeus, 1758) & & 0 & & & Tx, Tp \\
\hline 3 & 624 & Nemapogon cloacella (Haworth, 1828) & & $\mathbf{0}$ & & & $\mathrm{Tp}$ \\
\hline 4 & 481 & Cephimallota angusticostella (Zeller, 1839) & & 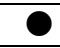 & & & $\mathrm{Tp}$ \\
\hline 5 & 568 & Infurcitinea olympica (G. Petersen, 1958) & & O & & & $\mathrm{Tp}$ \\
\hline 6 & 576 & Lichenotinea pustulatella (Zeller, 1852) & & O & & & $\mathrm{Tp}$ \\
\hline 7 & 579 & Ischnoscia borreonella (Millière, 1874) & & O & & & $\mathrm{Tp}$ \\
\hline 8 & 657 & Fermocelina liguriella (Millière, 1879) & & $\mathbf{0}$ & & & $\mathrm{Tp}$ \\
\hline 9 & 661 & Trichophaga tapetzella (Linnaeus, 1758) & & O & & & $\mathrm{Tp}$ \\
\hline 10 & 682 & Tinea nonimella (Zagulajev, 1955) & & $\mathbf{0}$ & & & $\mathrm{Tp}$ \\
\hline 11 & 700 & Monopis laevigella (D. \& S., 1775) & & 0 & & 0 & $\mathrm{Tp}$ \\
\hline 12 & 704 & Monopis obviella (D. \& S., 1775) & O & O & & 0 & $\mathrm{Tp}$ \\
\hline 13 & 705 & Monopis crocicapitella (Clemens, 1859) & & 0 & & & $\mathrm{Tp}$ \\
\hline 14 & 707 & Monopis imella (Hübner, 1813) & & O & & & $\mathrm{Tp}$ \\
\hline 15 & 709 & Monopis christophi (G. Petersen, 1957) & & $\mathbf{0}$ & & & $\mathrm{Tp}$ \\
\hline 16 & 710 & Monopis pallidella (Zagulajev, 1955) & & $\mathbf{0}$ & & & $\mathrm{Tp}$ \\
\hline \multirow[t]{2}{*}{17} & 711 & Monopis fenestratella (Heyden, 1863) & & O & & & $\mathrm{Tp}$ \\
\hline & & Fam. ACROLEPIIDAE & & & & & \\
\hline 18 & 1534 & Rhigognostis wolfschlaegeri (Rebel, 1940) & & & & $\mathbf{0}$ & $\mathrm{Tx}$ \\
\hline 19 & 1556 & Digitivalva pulicariae (Klimesch, 1956) & & 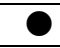 & & O & Stp, Tx \\
\hline \multirow[t]{2}{*}{20} & 1562 & Digitivalva granitella (Treitschke, 1833) & & O & & 0 & $\mathrm{Tp}$ \\
\hline & & Fam. DEPRESSARIIDAE & & & & & \\
\hline 21 & 1714 & Agonopterzx atomella (D. \& S., 1775) & O & & & & \\
\hline 22 & 1719 & Agonopterix arenella (D. \& S., 1775) & & O & & & $\mathrm{Tx}$ \\
\hline \multirow[t]{2}{*}{23} & 1738 & Agonopterix banatica (Georgesco, 1965$)$ & & $\mathbf{0}$ & & & $\mathrm{Tx}$ \\
\hline & & Fam. ALUCITIDAE & & & & & \\
\hline 24 & 5322 & Alucita cymatodactyla (Zeller, 1852) & & & & O & Stp \\
\hline 25 & 5323 & Alucita hexadactyla (Linnaeus, 1758) & & $\mathbf{0}$ & & O & $\mathrm{Tx}$ \\
\hline 26 & 5325 & Alucita huebneri (Wallengren, 1859) & & 0 & & 0 & $\mathrm{Tx}$ \\
\hline 27 & 5327 & Alucita grammodactyla (Zeller, 1841) & & $\mathbf{0}$ & & & Tx \\
\hline 28 & 5329 & Alucita desmodactyla (Zeller, 1847) & & O & & & $\mathrm{Tx}$ \\
\hline \multirow[t]{2}{*}{29} & - & Alucita bulgaria (Zagulajev, 2000) & & & & ○ & Tx \\
\hline & & Fam. PYRALIDAE & & & & & \\
\hline 30 & 5627 & Pyralis farinalis (Linnaeus, 1758) & & O & & & Tx \\
\hline 31 & 5632 & Aglossa caprealis (Hübner, 1809) & & $\mathbf{0}$ & & & Tx \\
\hline \multirow[t]{2}{*}{32} & 5633 & Aglossa pinguinalis (Linnaeus, 1758) & & $\mathbf{0}$ & & & Tx \\
\hline & & Fam. CRAMBIDAE & & & & & \\
\hline \multirow[t]{2}{*}{33} & 6607 & Pyrausta falcatalis (Guenée, 1854) & & O & & & $\mathrm{Tx}$ \\
\hline & & Fam. SATURNIIDAE & & & & & \\
\hline \multirow[t]{2}{*}{34} & 6795 & Saturnia spini (D. \& S., 1775) & & & & O & $\mathrm{Tx}$ \\
\hline & & Fam. SPHINGIDAE & & & & & \\
\hline 35 & 6843 & Macroglossum stellatarum (Linnaeus, 1758) & & $\mathbf{0}$ & & O & $\mathrm{Tx}$ \\
\hline
\end{tabular}




\begin{tabular}{|c|c|c|c|c|c|c|c|}
\hline 36 & 7847 & $\begin{array}{l}\text { Fam. GEOMETRIDAE } \\
\text { Gnophos furvata (D. \& S., 1775) }\end{array}$ & & • & & & Tx \\
\hline 37 & 7852 & Odontognophos dumetata (Treitschke, 1827) & & - & & & Tx \\
\hline 38 & 8028 & Timandra comae (A. Schmidt, 1931) & & & & - & Tx \\
\hline 39 & 8256 & Xanthorhoe fluctuata (Linnaeus, 1758) & & & & - & Tx \\
\hline 40 & 8258 & Xanthorhoe axybiata (Millière, 1872) & & & & - & $\mathrm{Tx}$ \\
\hline 41 & 8289 & Camptogramma bilineata (Linnaeus, 1758) & & - & & & Tx \\
\hline 42 & 8319 & Cosmorhoe ocellata (Linnaeus, 1758) & & & & - & Tx \\
\hline 43 & 8325 & Nebula nebulata (Treitschke, 1825) & & & & - & Tx \\
\hline 44 & 8391 & Hydriomena furcata (Thunberg, 1784) & & - & & & Tx \\
\hline 45 & 8411 & Melanthia procellata (D. \& S., 1775) & & - & & & Tx \\
\hline 46 & 8421 & Rheumaptera cervinalis (Scopoli, 1763) & & - & & & Tx \\
\hline 47 & 8427 & Triphosa sabaudiata (Duponchel, 1830) & - & - & - & - & Tx \\
\hline 48 & 8428 & Triphosa dubitata (Linnaeus, 1758) & - & - & $\boldsymbol{0}$ & - & Tx \\
\hline 49 & 8457 & Perizoma hydrata (Treitschke, 1829) & & - & & & Tx \\
\hline 50 & 8458 & Perizoma lugdunaria (Herrich-Schäffer, 1855) & & - & & & Tx \\
\hline 51 & 8496 & Eupithecia undata (Freyer, 1840$)$ & & & & - & Tx \\
\hline \multirow[t]{2}{*}{52} & 8681 & Acasis viretata (Hübner, 1799) & & - & & & Tx \\
\hline & & Fam. NOCTUIDAE & & & & & \\
\hline 53 & 8877 & Catocala elocata (Esper, 1787) & & & & - & Tx \\
\hline 54 & 8940 & Apopestes spectrum (Esper, 1787) & $\mathbf{0}$ & - & & - & Tx \\
\hline 55 & 8944 & Autophila dilucida (Hübner, 1808) & & - & & - & Tx \\
\hline 56 & 8945 & Autophila limbata (Staudinger, 1871) & & & & - & Tx \\
\hline 57 & 8948 & Autophila ligaminosa (Eversmann, 1851) & & & & - & Tx \\
\hline 58 & 8984 & Scoliopteryx libatrix (Linnaeus, 1758) & - & - & - & - & $\mathrm{Tx}$ \\
\hline 59 & 8995 & Hypena rostralis (Linnaeus, 1758) & & - & & - & Tx \\
\hline 60 & 8996 & Hypena obesalis Treitschke, 1829 & - & $\mathbf{0}$ & & - & Tx \\
\hline 61 & 8997 & Hypena obsitalis (Hübner, 1813) & - & & & & \\
\hline 62 & 8998 & Hypena palpalis (Hübner, 1796) & - & & & - & Tx, Stp \\
\hline 63 & 9305 & Pyrois effusa (Boisduval, 1828) & - & & & - & Tx \\
\hline 64 & 9490 & Mormo maura (Linnaeus, 1758) & - & - & & - & Tx \\
\hline 65 & 9638 & Dasypolia templi (Thunberg, 1792) & & & & - & Tx \\
\hline 66 & 10096 & Noctua pronuba (Linnaeus, 1758) & & - & & & Tx \\
\hline 67 & 10139 & Rhyacia simulans (Hufnagel, 1766) & & & & - & Tx \\
\hline 68 & 10163 & Spaelotis ravida (D. \& S., 1775) & & - & & & Tx \\
\hline \multirow[t]{2}{*}{69} & 10218 & Eugraphe sigma (D. \& S., 1775) & & $\mathbf{0}$ & & & Tx \\
\hline & & Fam. NYMPHALIDAE & & & & & \\
\hline 70 & 7247 & Inachis io (Linnaeus, 1758) & & - & $\boldsymbol{0}$ & - & Tx \\
\hline 71 & 7250 & Aglais urticae (Linnaeus, 1758) & & - & & 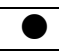 & $\mathrm{Tx}$ \\
\hline 72 & 7258 & Nymphalis polychloros (Linnaeus, 1758) & & $\mathbf{0}$ & & - & Tx \\
\hline 73 & 7312 & Lasiommata maera (Linnaeus, 1758) & & $\boldsymbol{0}$ & - & & Tx \\
\hline
\end{tabular}

\section{CONCLUSION}

Based on the literature, the cavernicolous habitats and ecological niches in which the studied species are found were determined.

Results show that 73 species of Lepidoptera, representing 10 families, were found in speleological habitats in the countries analyzed. The 73 identified species make up $80 \%$ of the 90 known species found in caves worldwide Turquin (1994), reflecting the richness of the fauna. Fifty-four species of Lepidoptera were identified in Romania, 35 in Bulgaria, 12 in Croatia and 5 in Serbia. The caves in eastern Serbia are found in the central part of the Carpatho-Balkan system. It is therefore realistic to deduce their faunistic potential to be around 50 species. The given quantitative data points out the inadequate level of research into Lepidoptera in the caves of Serbia.

The most abundant species are from the families of Tineidae and Noctuidae, with 17 species each. Analysis showed that the number of identified species depends on the targeted research of specialized lepidopterists. Beron (1994), who is not a lepidopterist, recorded only 16 species in the caves of Bulgaria. It was only the targeted research of experienced lepidopterists (Beshkov \& Petrov, 1996) that doubled this number. In Romania, there is a rich biospeleological tradition from the period of Emil Racoviță (E. Rakovitza, 1868-1947) and there are several lepidopterists, so that the number of identified species is greater. The number of species in Serbia and Croatia is small because no 
one has taken an interest in cavernicolous Lepidoptera. Just how neglected the faunistic study of this group is in Serbia is clear when compared to the cavernicolous systems in Luxembourg where 18 species of Lepidoptera have been identified (Werno et al., 2013).

The ecological presence of Lepidoptera in caves is determined by habitat and ecological niche. According to the degree of dependence of the identified Lepidoptera species on cavernicolous habitats, three groups of Lepidoptera are singled out: troglophiles (Tp), trogloxenes (Tx) and subtroglophiles (Stp) (Table 1). Interesting to this analysis are the troglophiles, organisms that are adapted to conditions of cave life but which are not exclusive to caves. The results show that there are 17 of this type of species. With the exception of the species Digitivalva granitella (Treitschke, 1833), the others belong to the Tineidae family. Robinson (1980), conducted a more detailed study of them as cave-dwelling Lepidoptera. Three of the mentioned species are also found in caves in Romania and Bulgaria, and they are most probably present in caves in Serbia. The number of these species is probably higher because in Serbia and Bulgaria there are no lepidopterists specializing in representatives of the Tineidae family. In Romania, this group of moth fauna is wellresearched and there is a book of national fauna dedicated to it (Cãpuşe, 1968). Six of the 17 mentioned species, N. granella, $N$. cloacella, C. angusticostella, M. laevigella, M. obviella and M. imella, are present in Serbian fauna, but are only found outside caves (Jakšić, 2016).

The ecological niches of all 73 identified Lepidoptera species can be divided into two groups: species that occupy the niche at the entrance of caves ("the Twilight Zone"), where temperature and humidity are variable and conditioned by the outside environment, and these are mostly trogloxene species. They are found here during winter hibernation, summer estivation, or by chance, in the search for temporary shelter. Here can also be found species that feed on fungi and lichens (fungivore or mycophagous), as well as those that feed on hair and feathers (keratinophilic), such as Monopis obviella (Denis \& Schiffermüller, 1775) and Monopis crocicapitella (Clemens, 1859).

Many bird species in Serbia, such as Neophron percnopterus, Gypaetus barbatus, Columba livia, Bubo bubo, Hirundo daurica, Pyrrhocorax graculus, etc. (Rašajski, 2000) build their nests at the entrances of caves. It is worth mentioning the moth species Galleria mellonella (Linnaeus, 1758), whose caterpillars live in the nests of wasps, bees and bumblebees (often built at cave entrances) and feed on wax. Unlike them, the second group - troglophile species occupy the interior of caves, without light and with a relatively constant temperature and humidity. They are mostly found on the guano of cave-dwelling bats or carcasses of animals that enter the caves before dying.

The data indicate that the greatest faunistic potential in Serbian caves is that of troglophile species of Lepidoptera, primarily representatives of the Tineidae family. The larvae of Tineidae species feed on fungi, lichens (fungivores), hair, bird feathers, nails, claws, etc. (keratophiles) and the body parts of dead animals and feces (detritivores or saprovores). The fossils of many groups of vertebrates found in Balkan caves confirm the long existence of these systems, i.e. the long-term adaptation of species from the Tineidae family to the specific habitat conditions. Many species brought their prey into the caves; others died in them. Such organic mass is an ideal ecological niche for the larvae of Tineidae.

Table 2. Sites of bats in Serbian caves: +++- large colonies with over 1000 individuals; ++ - middle sized colonies with several hundred individuals; + - small colonies with 50-100 individuals. Type of habitat according to the IUCN classification scheme: $1.4 .2-$ deciduous broadleaved forests; 3.5.3 - warm and temperate grasses and shrubs; 5.1 - perennial rivers, brooks, streams (including waterfalls) (according to (Paunović, 2016) and simplified)

\begin{tabular}{|c|c|c|c|c|c|c|c|c|c|}
\hline 总 & 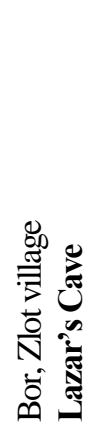 & 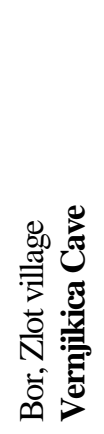 & 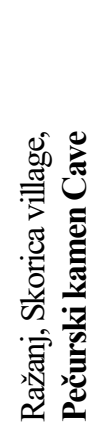 & 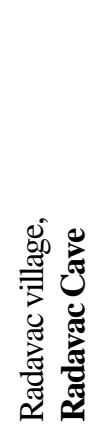 & 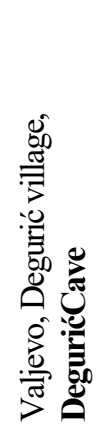 & 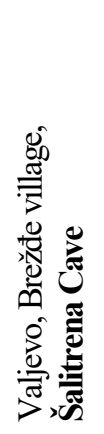 & 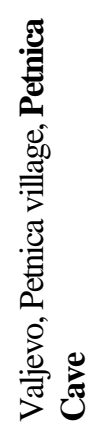 & 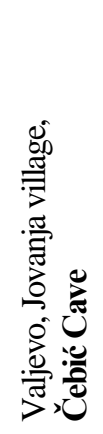 & 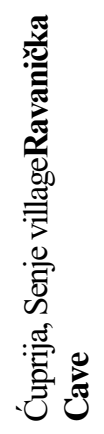 \\
\hline ma.s.l. & 308 & 450 & 430 & 631 & 240 & 285 & 209 & 330 & 235 \\
\hline UTM & EP77 & EP77 & EP54 & DN43 & DP19 & DP29 & DP19 & DQ00 & EP36 \\
\hline $\begin{array}{l}\text { Type of habitat around the } \\
\text { cave }\end{array}$ & 3.5 .3 & 3.5 .3 & 1.4 .2 & 1.4 .2 & 5.1 & 5.1 & 1.4 .2 & 3.5.3 & 3.5 .3 \\
\hline Colony size & +++ & +++ & +++ & +++ & +++ & +++ & ++ & ++ & ++ \\
\hline $\begin{array}{l}\text { Number of bat } \\
\text { Species }\end{array}$ & 13 & 10 & 7 & - & 5 & 4 & 14 & 11 & 8 \\
\hline
\end{tabular}


Representatives of the Tineidae family that are detritivores prefer the guano of bats (Mammalia: Chiroptera). Ulrich et al. (2007), analyzed the correlation of the faunistic abundance of bats in 58 European countries with the size of territory, altitude, temperature conditions (the number of days in a year with temperatures $<0^{0} \mathrm{C}$ ), richness of vascular flora and distance from Turkey. Optimal conditions are in the geographical latitude of $46^{\circ} \mathrm{N}$, where Croatia has 34 bat species, and Serbia 30 (Paunović, 2016). Luxembourg has 18 species of bat and the same number of cave-dwelling Lepidoptera species, indicating the possibility that Serbia could have 50 species of cave-dwelling Lepidoptera. Altitude is also an important factor for the distribution of bats; the majority prefers altitudes up to $600 \mathrm{~m}$, as has been established for bats in Serbia (Paunović, 2016). The richness of vascular flora has no effect on the number of bat species. The presented data suggest that the presence of bats is the key factor as to which speleological structures in Serbia should be researched in the search for troglophilic species of Lepidoptera. It is fortunate that Paunović (2016) provided data that are important to this study. The author points out that the most important habitats for bats in Serbia are caves, and he provides information about the character of these habitats (Table 2). To summarize, we can conclude that despite the diversity of cavernicolous habitats on the Balkan Peninsula and in Serbia, there has not been enough research into Lepidoptera fauna. The reason for this is the appeal of other groups, particularly with respect to faunistic richness and endemism, which have attracted the attention of researchers away from Lepidoptera. Additionally, there is the traditional belief that there are no Lepidoptera in caves, that their presence is occasional and fortuitous, that they are not really cave organisms. This belief was dismissed by Robinson (1980) who, in the case of species from the Tineidae family, pointed out that 11 of the 20 identified species permanently exist in cave populations and have not been found outside, and that their larvae feed on guano (guanophiles). The presented data show that the study of the cavernicolous fauna of Lepidoptera in Serbia is both justified and necessary.

\section{REFERENCES}

Anonymous, 2007. EUNIS habitat classification. 2007 (Revised descriptions 2012). Retrieved from http://www.eea.europa.eu/themes/biodiversity/eunis/eunishabitat-classification/habitats/eunis-habitats-complete-withdescriptions.xls

Beron, P. 1994. Résultats des recherches biospéléologiques en Bulgarie de 1971 à 1994 et liste des animaux cavernicoles Bulgares.Sofia: Editions de la Féderation bulgare de Spéléologie., pp. 1-137.

Beron, P. 2016. Terrestrial cave invertebrates of the Vrachanska Planina Mountains. - In: Bechev, D. \& Georgiev, D. (Eds.): Faunistic diversity of Vrachansky Balkan Nature Park. ZooNotes, 3, pp. 185-230. Suppl. Plovdiv..
Beshkov, S., \& Petrov, B. 1996. A catalogue of the Bulgarian Lepidoptera species reported and collected from the caves and galleries in Bulgaria (Insecta Lepidoptera). Atalanta Würzburg, 27(1/2), pp. 433-448.

Jeannel, R., \& Stanković, S. 1924. Prilog poznavanju pećinske faune i pećina u Srbiji. Glas Srpske kraljevske akademije, Beograd, 113(50), pp. 97-105.

Jakšić, P. 2005. Staništa i ekološke niše u speleološkim objektima istočne Srbije prema savremenim klasifikacionim sistemima (CORINE, EUNIS). . In: Drugi naučni skup o geonasleđu Srbije, 2004-06-22, Beograd. , pp. 189-196

Jakšić, P. 2016. Tentative Check List of Serbian Microlepidoptera. Ecologica Montenegrina Podgorica, 7, pp. 33-258.

Jeannel, R., \& Racovitza, E.G. 1929. Énumération des grottes visitées 1918-1927 (septieme serie). Archives de zoologie expérimentale et génèrale Paris, 68, pp. 293-608. II.

Jovanović, Đ. 1891. Sićevačka klisura, pećine, dupke i potkapine. Otadžbina, Beograd, 29, pp. 401-419.

Karsholt, O., \& Razowski, J. 1996. The Lepidoptera of Europe. A Distributional Checklist.Stenstrup: Apollo Books., pp. 1380.

Kučinić, M. 2002. Lepidoptera and Trichoptera. In: GottsteinMatočec, S. (ed.) An overview of the cave and interstitial biota of Croatia. Natura croatica, Zagreb, 11(1), pp. 1-112. (Suppl.).

Paunović, M. 2016. Rasprostranjenje, ekologija i centri diverziteta slepih miševa (Mammalia: Chiroptera) u Srbiji.Univerzitet u Beogradu - Biološki fakultet., pp. 1-474. Doktorska disertacija I-IX +.

Pretner, E. 1963. Biospeleološka istraživanja u Srbiji. Poročila Acta Carsologica, Ljubljana, 3, pp. 139-147.

Rašajski, J. 2000. Ptice Srbije (Birds of Serbia).Novi Sad: Prometej.

Remy, P. 1953. Description des grottes Yougoslaves. Bulletin du museum d'histoire naturelle du Pays Serbe, Beograd, 5-6, pp. 175-233.

Robinson, G. 1980. Cave dwelling tineid moths: A taxonomic review of the World species (Lepidoptera: Tineidae). Trans. British Cave Research Assoc, 7(2), pp. 83-120.

Turquin, M.J. $1994 . \quad$ Lepidoptera. Encyclopedia Biospeleologica. In: C. Juberthie\& V. Decu Eds., . Moulis Bucarest: Société Biospéologie., pp. 333-339 I.

Cãpuşe, I. 1968. Fauna Republicii Socialiste Romãnia. Insecta Volumul XI, Fascicula 9. Fam. Tineidae.Bucuresti: Editura Academiei RS Romãnia.

Ćurčić, B.P.M., Dimitrijević, R.N., Makarov, S.E., Lučić, L.R., Karamata, O.S., \& Tomić, V.T. 1997. The Zlot Cave: A unique faunal refuge (Serbia, Yugoslavia). Arch. Biol. Sci. Belgrade, 49(3-4), pp. 29-30.

Ulrich, W., Sachanowicz, K., \& Michalak, M. 2007. Environmental correlations of species richness of European bats (Mammalia: Chiroptera). Acta chiropterologica, 9(2), pp. 347-360.

Werno, A., Weber, D., \& Meyer, M. 2013. Schmetterlinge (Insecta, Lepidoptera) aus Höhlen des Großherzogtums Luxemburg. In: Weber, D. (ed.): Die Höhlenfauna Luxemburgs. Ferrantia, 69, pp. 388-394. 